\title{
「緎維分野におけろファジ侂用」の特集にあたって
}

\section{今岡 春樹*}

纎維分野は大变広範な領域を意味する。瀻維は 産業資材や医学の領域でも用いられるが，一つの 代表は衣服である，衣服ができるまでには，多く のプロセスが必要である。纎維一系一布一衣服と いうのがその大きな流れである。 そして，この流 れは直線ではなく, 各工程での評価によるフィー ドバックが常時行われる．繊維から糸を作る工程, 糸から布を作る工程, 布から衣服を作る工程は, 様々な方式があり，またそれぞれ小工程に分離さ れている。例えば，系から布を作る工程には，製 織工程, 染色工程などの小工程がある。布から衣 服を作る工程には, 企画・設計工程, 生産工程な どの小工程がある.

このように複雑な工程の連銷の結果, 衣服が生 み出されることになるが, 各工程での問題点はほ とんど制御と評価の問題である。織機であればそ の機構の制御, 染色であればその化学プロセスの 制御, さらにそれぞれ出来映えの評価が必要とな る. 計算機出現以前には, 制御の問題は巧妙な機 構によって, 評価の問題は専門家の経験と勘によ つて解決されてきた，計算機が出現してから徐々 に, 計算機制御と計算機を用いた評価に移行して 来た。
しかし, 制御対象や評価対象が極めて複雑な場 合も多く, そのような場合には従来の尃門家の調 整や評価が勝っていた．そこでファジィ制御やフ アジィ推論のように, ファジィ集合を用いた方式 によって, 専門家の知識を活用しようという試み がなされている。

本特集では，このような技術の現状を紹介いた だいた．染色における色の評価問題をファジイ推 論で解決しようとする技術 2 件, 織機のファジィ 制御に関する技術 1 件, 衣服を着用する人体モデ ルの動作をファジィ言語で指示する技術 1 件, 市 場分析におけるファジィデータの使用に関する技 術 1 件, 重回帰分析でのファジィデータの使用に 関する技術 1 件，の 6 件を解説いただいた。

纎維製品は人工物であるが，もともと均一では なく(例えば絾維長)，また人間の身近にあるため， 視覚や触覚によって最終的に評価される。このた め, 人間の感性による評価を直接受ける製品であ って，完全に均一であると逆に好まれない，防し わ加工が重要であると同時にしわ加工も重要であ る。このように瀻維製品は本質的にファジィであ る.ファジィという言菄は, 布の風合いを表し, 毛羽立った感触や見え方を意味する.このように ファジイな製品を作るために，積極的にファジィ な手法を導入しょうという試みが, 今回の特集で ある。
* Haruki IMAOKA .奈良女子大学 生活環境学部

Faculty of Human Life and Environment, Nara Women's University 